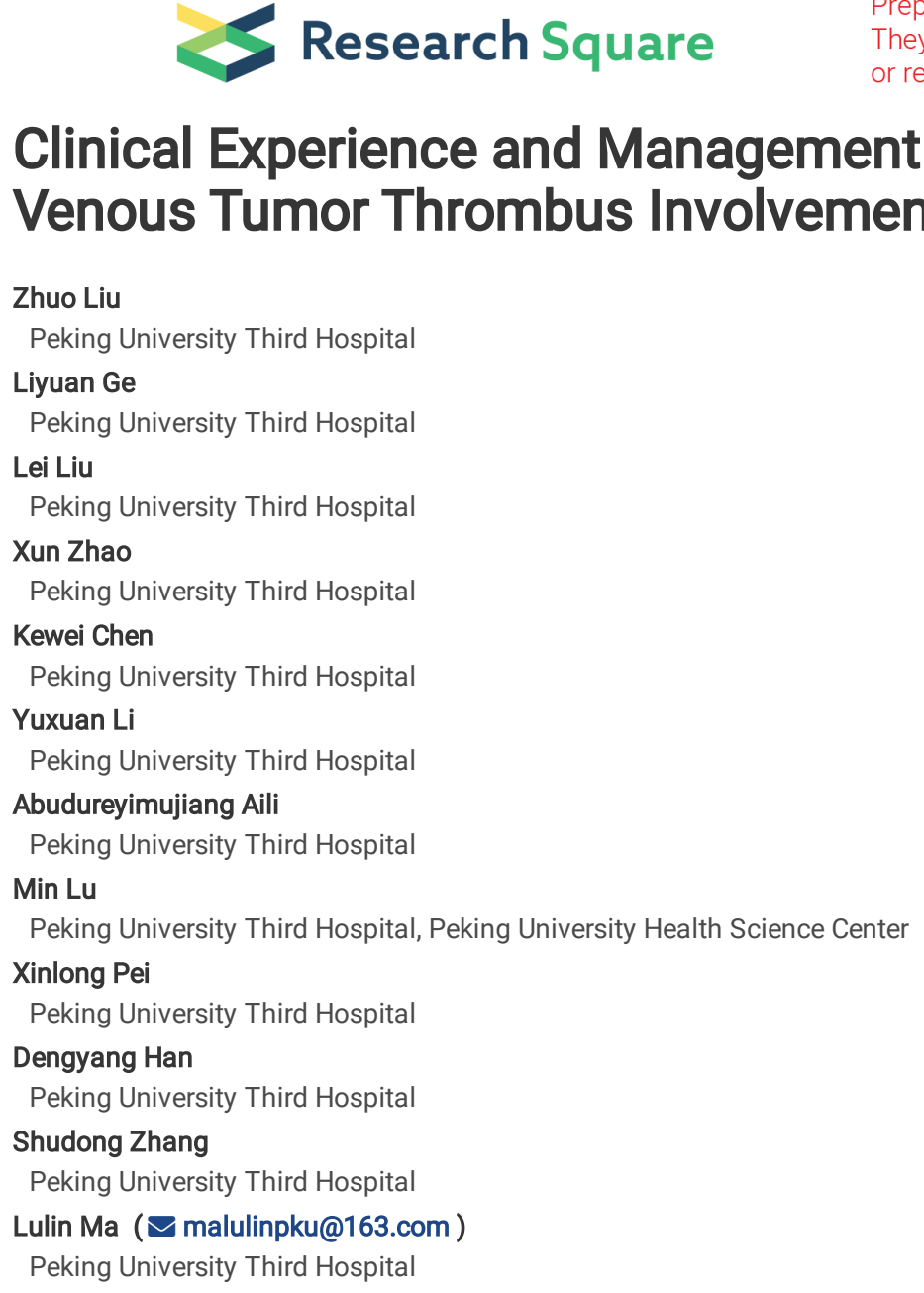

\title{
Clinical Experience and Management Strategy of Retroperitoneal Tumor With Venous Tumor Thrombus Involvement
}




\section{Abstract}

Background: To report the surgical management, complications, and outcomes for patients with retroperitoneal tumor and venous thrombus

Methods: We retrospectively analyzed 19 cases of retroperitoneal tumor with venous tumor thrombus from August 2015 to March 2021 . According to the characteristics of surgical techniques, a new tumor thrombus PUTH grading system was proposed.

Results: There were 2 cases of PUTH-1a, 2 cases of PUTH-1b, 6 cases of PUTH-2, 6 cases of PUTH-3,3 cases of PUTH-4. All the operations were successfully performed in 19 patients. Among them, 5 cases (26.3\%) were operated by completely laparoscopic approach and 13 cases (68.4\%) were operated by open approach. One case (5.3\%) was converted from laparoscopic approach to open approach. 5 cases experienced postoperative complications, the incidence was $26.3 \%$. All the cases were followed-up for a median of 14 months. Cancer associated death were occurred in 3 cases. Distant metastases were occurred in 7 cases.

Conclusions: In this study, we proposed a new tumor thrombus grading system based on the anatomical characteristics of retroperitoneal tumors with venous tumor thrombus. Retroperitoneal tumor resection and removal of venous tumor thrombus are safe and effective in the treatment of such diseases.

\section{Introduction}

Retroperitoneal tumors, such as adrenocortical carcinoma, adrenal pheochromocytoma, and retroperitoneal leiomyosarcoma, etc., represents a group of anatomically similar tumors occurring in retroperitoneum (1-3). Owing to the invasive feature of tumor, those patients often accompanied by venous system invasion at initial diagnosis $(4,5)$. Surgical extirpation is the cornerstone of treatment in those patients. While radical nephrectomy and thrombectomy has been widely adopted in treating renal cell carcinoma with thrombus, the role of surgery in treating retroperitoneal tumors remains controversial and preoperative surgical planning remains a challenge(6-9).

Open or laparoscopic surgery with en-bloc excision has been the mainstay for primary and recurrent retroperitoneal tumors due to the lack of effective adjuvant therapy(10-12). There are to date no clear guidelines for surgical treatment of retroperitoneal masses with venous involvement due in part to still insufficient cases and the lack of prospective randomized trials(13). Due to the rarity of this disease subset, it is crucial to summary the surgical decisionmaking strategy and examine the patients who undergo thrombectomy to describe their outcomes and complications.

We present a contemporary series of 19 patients diagnosed of retroperitoneal tumors with venous involvement in which radical resection and thrombectomy was conducted by means of open or laparoscopic surgery. According to the characteristics of surgical techniques, we proposed a new tumor thrombus management strategy stratification system, and its clinicopathological characteristics and prognosis were summarized to improve the diagnosis and treatment experience.

\section{Materials And Methods}

After Peking University Third Hospital Ethic Committee review board approval, a retrospective analysis was conducted on 19 consecutive cases diagnosed of retroperitoneal tumors with venous thrombus from August 2015 to March 2021. The clinical presentation, laboratory and imaging findings, extent and level of cava involvement, operative findings and technical details estimated blood loss, postoperative complications, and overall survival were calculated.

According to the clinical manifestations of patients, they can be divided into those with no obvious clinical symptoms, those with only local symptoms (such as hematuria, lumbago, abdominal mass, etc.), those with only systemic symptoms (such as fatigue, weight loss, fever, etc.), and those with both local and systemic symptoms. Performing urinary system enhancing CT to confirm the clinical diagnosis of retroperitoneal tumors. To determine whether there is hilar lymph node metastasis and distant metastasis of abdominal organs. Performing inferior vena cava enhanced magnetic resonance imaging to identify the characteristics of tumor thrombus. The length and width of tumor thrombus in inferior vena cava were measured in coronal position. The presence or absence of thrombus (non-tumor emboli) was judged by the delayed period of MRI enhancement(14). According to the imaging characteristics, whether the tumor thrombus invaded the vessel wall was evaluated. Performing chest CT to determine whether there is lung metastasis. For patients with bone pain and central nervous system symptoms, bone scan and head MRI should be performed respectively, to exclude bone metastasis and brain metastasis. When necessary, PET-CT were used to evaluate systemic metastasis.

All patients were received multi-disciplinary treatment (MDT) discussion before operation. The MDT team includes urology, anesthesiology, radiology, ultrasound diagnosis, oncology, pathology, general surgery, and cardiac surgery. The MDT clinical treatment decision was carried out based on comprehensive opinions from various disciplines, including preoperative preparation, surgical methods, coping strategies for special conditions during operation, prevention, and treatment strategies for postoperative complications, etc.

According to the patients' surgical approaches, they can be divided into complete laparoscopic approach, open approach, and laparoscope-to-open approach. In previous studies, we described the incision, body position and puncture location of different surgical approaches.

Firstly, we used the Mayo grading system, a classical grading method for renal cell carcinoma and venous tumor thrombus, to evaluate retroperitoneal tumor patients with venous tumor thrombus(15). At the same time, we classified all cases using Peking University Third Hospital (PUTH) grading system. (Figure 1) Based on the PUTH grading system reclassification, we chose the corresponding surgical approach. (Table 1) For PUTH 1a grade tumor thrombus in the left adrenal gland, the left central adrenal vein can be cut off with Hem-o-lok clamp or straight-line cutter. For PUTH 1b grade tumor thrombus in the left adrenal gland, Satinsky forceps can be used to partially block the inferior vena cava. Then, the left renal vein was cut during the operation, and the tumor thrombus of the left adrenal gland and the central adrenal vein were removed, and then the left renal vein was sutured to remove the blockage. If tumor thrombus invades 
the wall of left renal vein, Hem-o-lok clamp or straight-line cutter should be used to cut off the left renal vein. The left kidney only circulates through the left gonadal vein or collateral branch of the ascending lumbar vein. For adrenal PUTH grade 2 tumor thrombus, the tumor thrombus has entered the inferior vena cava, the proximal end of the tumor thrombus is located under the liver, and the distal end of the tumor thrombus is located above the level of renal vein. During the operation, the inferior vena cava at the distal end of the tumor thrombus and the inferior vena cava at the proximal end of the tumor thrombus can be blocked in turn by the vascular blocking tape, and then the inferior vena cava can be cut open to remove the thrombus. If the distal end of the tumor thrombus is born against the blood flow direction, it can be located below the level of renal vein. During the operation, the blood vessel blocking tape was used to block the inferior vena cava of the distal end and the proximal end of the tumor thrombus in turn, It is also necessary to block the blood reflux of the left renal vein. For PUTH grade 3 tumor thrombi of adrenal gland, the proximal end of tumor thrombi reaches the level of retroliver. During the operation, it is necessary to use the technique of liver turning, break off the liver ligament, and expose and free the inferior vena cava behind the liver. The first hepatic portal was dissociated by Pringer method(16). The inferior vena cava, the first hepatic portal vein, the left renal vein, and the inferior vena cava near the heart end of the tumor thrombus were blocked by the vascular blocking belt in turn, and then the inferior vena cava was cut to remove the thrombus. For PUTH 4 grade tumor thrombus of right adrenal gland, we can first try to open diaphragm without thoracotomy, that is, cut diaphragm central tendon around vena cava or cut diaphragm directly. Squeeze gently to squeeze the tumor thrombus into inferior vena cava, so that the tumor thrombus changes from above diaphragm to below diaphragm, and then take out the tumor thrombus. Or open chest to establish cardiopulmonary bypass. Incision of right atrium to remove thrombus under hypothermic cardiac arrest or non-cardiac arrest. The modified Clavien grading system was used to evaluate postoperative complications(17). Grade III or higher complications were defined as severe complications.

Follow-up was conducted for the first time within one month after operation, focusing on postoperative complications. Patient follow-up was performed every 3-6 months within the first 2 years. Follow-up was performed every 6-12 months 2 years after operation. Follow-up was carried out every year after 5 years. For patients with residual tumor during operation or recurrence or distant metastasis after operation, Tyrosine kinase inhibitor was used for treatment. And the curative effect and adverse reaction of the drug were detected.

\section{Results}

\subsection{Patient Demographics}

Between August 2015 and March 2021, 19 patients with retroperitoneal tumor undergoing radical resection and thrombectomy were included in this study. Data including age, sex, tumor burden, were listed in Table 2-3. The median age of all patients at the time of surgical treatment was 42 years (range 1669 years). Among the 19 patients, there were 7 males and 12 females. The body mass index ranged from 18.3 to $36.2 \mathrm{~kg} / \mathrm{m}^{2}$, and the median BMI was 24.1 $\mathrm{kg} / \mathrm{m}^{2}$. Retroperitoneal tumors were located on the right side in 13 cases and on the left side in 6 cases. The median tumor diameter was $9.1 \mathrm{~cm}$ (range 2.8 $18.3 \mathrm{~cm})$. The median tumor thrombus length and width was $4 \mathrm{~cm}(1.0-12.3 \mathrm{~cm})$ and $2.3 \mathrm{~cm}(1.0-3.9 \mathrm{~cm})$, respectively.

According to the location of retroperitoneal tumors and thrombus level, we classified them into 5 different grades, named as PUTH grading system. The five grades were defined as follows: PUTH-1a: tumor thrombus was confined in central adrenal vein;PUTH-1b: a left side retroperitoneal tumor with thrombus extending into the left renal vein along the left central adrenal vein, but it does not reach into the inferior vena cava;PUTH-2: tumor thrombus invades inferior vena cava and its proximal end is located under liver;PUTH-3: tumor thrombus invades inferior vena cava and its proximal end is located behind the liver.;PUTH-4: tumor thrombus invaded inferior vena cava and reached above diaphragm. The preoperative clinical data of 19 patients are shown in Table 4.

\subsection{Intra-Operative Outcomes}

Among them, 5 cases (26.3\%) were operated by complete laparoscopic approach, and 13 cases (68.4\%) were operated by open approach. One patient (5.3\%) changed from laparoscopic approach to open approach. 18 patients were operated by radical resection of retroperitoneal tumor and venous tumor thrombectomy, and 1 patient underwent palliative retroperitoneal tumor resection due to the complete adhesion between thrombus and vessel wall. Of the 19 patients, 13 patients preserved the ipsilateral kidney during operation, and 6 cases removed the ipsilateral kidney. The median operation time was 342 mins. (range 153-575 mins) The median intraoperative blood loss was $1300 \mathrm{ml}$ (range $200-4500 \mathrm{ml}$ ). Fourteen of the 19 patients (73.7\%) received intraoperative blood transfusion; the median transfusion requirement was 4 units (range: 2-6 units). (Table 5)

\subsection{Surgical Outcomes}

Among 19 patients, 12 tumors originated from adrenal tissue, including 6 adrenal cortical carcinoma, 3 pheochromocytoma, 1 paraganglioma, 1 adrenal adenoma and 1 adrenal neuroblastoma. There were 7 cases of other retroperitoneal tumors not from adrenal tissue, including 4 leiomyosarcomas, 1 clear cell carcinoma of kidney and 1 Ewing sarcoma. Pathological type was unclear in 1 case. Of 19 patients, 6(31.6\%) had vessel wall invasion. There were 2 cases $(10.5 \%)$ with inferior vena cava thrombosis (non-tumor thrombus). Lymph node metastasis was found in 3 patients (15.8\%).

No perioperative deaths were occurred during the first 30 days after the surgery. Postoperative complications occurred in 5 patients, with an incidence of $26.3 \%$. Among them, there were 3 cases with anemia (Clavien grade 2), 1 case with wound infection (Clavien grade 1 ) and 1 case with pulmonary embolism (Clavien grade 2). 3 patients recovered from postoperative anemia after red blood cell suspension transfusion. The patient with wound infection had delayed union after two-week wound dressing. The patient with pulmonary embolism recovered after treating with low-molecular-weight heparins injection. The median postoperative hospital stay was 8 days.

\subsection{Oncological Outcomes}

All cases were followed up on time with a median follow-up of 14 months ranging from 3 to 69 months. Cancer associated death occurred in 3 cases. One patient died at the 7 months after operation owing to multiple organ metastasis. The other 2 patients experienced liver metastasis and retroperitoneal

Page $3 / 11$ 
recurrence at postoperative 10 months and 12 months, respectively. These two patients died of tumor progression at 11 th and 14 th postoperative months, respectively. Another 4 patients developed metastases during the follow up and were still receiving systematic therapy at the last follow up. One patient (Case 1) remained alive after over 5 years but need adjuvant systemic therapy (Sunitinib) for the treatment of lung metastasis. Case 4 received radiotherapy for the liver metastasis at 10 th postoperative months. Another patient (Case 5) received chemotherapy for retroperitoneal recurrence at the 3th postoperative months. Case 18 received erlotinib for diaphragmatic metastasis at the 9th postoperative months. (Table 6)

\section{Discussion}

At present, most of research concerning venous thrombus focus on renal cell carcinoma. However, there are few studies on adrenal tumors or other retroperitoneal tumors with venous tumor thrombus $(13,18)$. Mayo thrombus grading system is commonly used for evaluation in renal cell carcinoma(15). Mayo classification mainly considers the level of tumor thrombus. Different Mayo grades correspond to different surgical procedures, surgical difficulties, and complications. Some studies suggest that the higher the Mayo grade, the worse the prognosis of patients. However, Mayo grading is mainly applied to renal cell carcinoma with inferior vena cava tumor thrombus. Retroperitoneal tumors with venous tumor thrombus, represented by adrenal tumors, are different from classical renal cell carcinoma with venous tumor thrombus in anatomical structure and characteristics. First, in tumor location, kidney tumor is located inside the kidney, while adrenal tumor is located at the upper pole of the kidney, or between liver and kidney or between spleen and kidney. It determines that the proximal end of venous thrombus is often higher. The difficulty of operation is the dissociation of tumor thrombus near the proximal end. In this study, according to the traditional Mayo classification method, 10 patients were classified as Mayo II, but they still needed to free their liver and cut off the liverrelated ligaments to expose the posterior inferior vena cava. It is necessary to block the first hepatic portal vessel to reduce bleeding. These procedures are usually applied to patients with mayo grade III tumor thrombus in renal cell carcinoma venous tumor thrombus. Second, adrenal tumors are closer to the liver or spleen. Especially, right adrenal tumors often adhere to or invade the liver, which can easily cause bleeding during operation. It may increase the difficulty of operation. It poses a higher challenge to the safety of surgery. Thirdly, there are great differences in anatomical characteristics between the central adrenal vein and the renal vein. For renal cell carcinoma, the tumor grows from the kidney into the renal vein, and then directly enters the inferior vena cava along with the blood reflux direction. It is different for adrenal tumors. There are also great differences between left adrenal tumors and right adrenal tumors. Right adrenal tumors can enter the inferior vena cava after entering the right central adrenal vein. The left adrenal tumor first entered the left renal vein, and then grew along the left renal vein into the inferior vena cava.

Therefore, there is a big difference between the surgical treatment of adrenal tumor with venous thrombosis and traditional renal cell carcinoma with venous thrombosis. At present, there is no corresponding grading system for adrenal tumors or retroperitoneal tumors with venous tumor thrombus. In this study, we put forward PUTH scoring system. In PUTH 1 grade, according to the different sides and the different relationship with renal vein, they were further divided into $1 \mathrm{a}$ stage and $1 \mathrm{~b}$ stage. Among them, stage $1 \mathrm{~b}$ is mainly suitable for patients with left adrenal tumor thrombus. The tumor thrombus entered the left renal vein along the left central adrenal vein, but did not enter the inferior vena cava. we can use Satinsky forceps to partially block the inferior vena cava, then cut the left renal vein, remove the left adrenal tumor and the tumor thrombus in the central adrenal vein, suture the left renal vein囚and then remove the blockage. If the tumor thrombus does not invade the vein wall of the left kidney, the left kidney can be preserved. However, for tumor thrombus invading the left renal vein wall, Hem-o-lok clamp or straight-line cutter should be used to cut off the left renal vein. The left kidney depends on the collateral circulation such as gonad vein and lumbar ascending vein for reflux. If adrenal tumor thrombus extensively invades the left renal vein, it requires simultaneous resection of the left kidney to ensure radical resection of the tumor even the left renal is not affected. The treatment method for PUTH grade 2 to 4 is similar to mayo grade II to IV. The difference lies in the different position of the distal end of the tumor thrombus, and the surgical procedures. If the distal end of the tumor thrombus is above the level of renal vein, it is necessary to block the distal vena cava of cancer thrombus and the proximal vena cava of cancer thrombus in turn by using the vascular blocking belt, and then cut the inferior vena cava to remove the thrombus. If the distal end of the tumor thrombus is below the level of renal vein, vascular occlusion needs to block the blood reflux of the healthy renal vein at the same time.

In terms of surgical approach, 14 patients (70\%) chose the open approach. With the widely application of minimally invasive technology, many low-grade cancer thrombectomy can be completed under complete laparoscopic or robotic approach, but open approach is still an irreplaceable traditional and effective method for treating tumor thrombus(19). In adrenal tumors associated with venous tumor thrombus, the proportion of open approach is very high. This is largely determined by the operation space. Because of the existence of ipsilateral kidney, the space is extremely narrow, which constrains the application of minimally invasive technique in adrenal tumor with venous tumor thrombus. In addition, as adrenal tumors are in the upper pole of kidney, the proximal end of venous tumor thrombus is often higher. To fully expose the proximal end of cancer thrombus, it is necessary to free the liver during operation, but these operations are technically difficult under minimally invasive approach. Among adrenal tumors, there are 6 cases of adrenocortical carcinoma. Moreover, laparoscopic approach may increase the risk of tumor implantation and diffusion caused by tumor rupture.

Whether the ipsilateral kidney should be removed for adrenal tumors. Our experience is to preserve the ipsilateral kidney as much as possible. If one of the following situations occurs, resection of the ipsilateral kidney can be considered: 1 . The adrenal tumor is seriously adhered to the ipsilateral kidney, or the tumor surrounds the hilar blood vessel and cannot be separated; 2. Preoperative imaging suggests that adrenal tumors invade the ipsilateral kidney; 3 . The tumor thrombus extensively invaded the blood vessel wall of the ipsilateral renal vein, and the collateral venous circulation could not be compensated.

Adrenal tumors with venous tumor thrombus are often of high grade, transesophageal ultrasound plays a critical role in monitoring thrombus during operation(20). After anesthesia induction, patients can be examined by transesophageal ultrasound before, during and after thrombectomy. Before thrombectomy, vena cava wall invasion could be judged by monitoring blood flow between tumor thrombus and vessel wall. During thrombectomy, transesophageal ultrasonography can evaluate that whether the inferior vena cava vascular occlusion band is placed above the proximal end of tumor thrombus, and dynamically observe the whole process of tumor thrombectomy. After resection of tumor thrombus, transesophageal ultrasonography was performed to observe whether there was residual tumor thrombus in vena cava. Compared with the "static" and "past" information of preoperative imaging examination such as CT or MRI, the real-time and dynamic monitoring of heart, inferior vena cava and intraluminal tumor thrombus by transesophageal 
ultrasound can further clarify and even correct the preoperative diagnosis, It is very important for surgical decision-making and operation to provide real-time information of tumor thrombus.

There are several limitations in this study. Firstly, the PUTH grading system described in this study is suitable for common adrenal vein anatomy. But there may be venous variation in a few patients. This requires surgeons to read the me carefully before operation and make individualized surgical plans according to the specific characteristics of each patient. Second, the sample size of patients in this group is relatively small. This is mainly due to the low incidence of venous thrombosis in adrenal tumors or retroperitoneal tumors. A multicenter study with larger sample size is needed for further verification. Thirdly, the main classification basis of the adrenal tumor venous thrombus system in this paper is determined according to the anatomical position of the level of tumor thrombus. It's essential to differentiate the pathological subtypes of tumors. However, it's difficult to divide into subgroups as there is only one case of some pathological type.

\section{Conclusions}

To sum up, in this study, we put forward a new classification system of tumor thrombus according to the anatomical characteristics of adrenal tumors or other retroperitoneal tumors associated with venous thrombosis. Retroperitoneal tumor resection and venous tumor thrombectomy are safe and effective in treating these diseases.

\section{Declarations}

\section{Conflict of Interest}

The authors declare that there is no conflict of interest.

Author Contributions: Conceptualization, Z.L. and L.G.; methodology, L.L. K.W. and Y.L.; validation, X.Z. and A.A.; formal analysis, X.P. and K.C; investigation, X.Z; resources, M.L.; data curation, D.H.; writing-original draft preparation, Z.L. and L.G.; writing-review and editing, L.M.; visualization, S.Z.; All authors have read and agreed to the published version of the manuscript.

\section{Acknowledgments}

No.

\section{Funding}

This research received no external funding.

\section{Institutional Review Board Statement}

The study was conducted according to the guidelines of the Declaration of Helsinki, and approved by the Peking University Third Hospital Ethic Committee (protocol code 2021-245-02 and date of approval 29 May 2021).

\section{Informed Consent Statement}

Informed consent was obtained from all subjects involved in the study.

\section{Data Availability Statement}

Data supporting reported results may be obtained upon request to the corresponding author.

\section{References}

1. Improta L, Tzanis D, Bouhadiba T, Abdelhafidh K, Bonvalot S. Overview of primary adult retroperitoneal tumours. Eur J Surg Oncol. 2020;46(9):1573-9.

2. Sassa N. Retroperitoneal tumors: Review of diagnosis and management. Int J Urol. 2020;27(12):1058-70.

3. Lubner MG, Hinshaw JL, Pickhardt PJ. Primary malignant tumors of peritoneal and retroperitoneal origin: clinical and imaging features. Surg Oncol Clin $\mathrm{N}$ Am. 2014;23(4):821-45.

4. Schwarzbach MHM, Hormann Y, Hinz U, Leowardi C, Böckler D, Mechtersheimer G, et al. Clinical results of surgery for retroperitoneal sarcoma with major blood vessel involvement. J Vasc Surg. 2006;44(1):46-55.

5. Quinones-Baldrich W, Alktaifi A, Eilber F, Eilber F. Inferior vena cava resection and reconstruction for retroperitoneal tumor excision. J Vasc Surg. 2012;55(5).

6. Fairweather M, Raut CP. Nephrectomy for Retroperitoneal Sarcoma: Stay Calm and (Cautiously) Carry On. Ann Surg Oncol. 2021;28(3):1275-7.

7. Nooromid MJ, Ju MH, Havelka GE, Kozlowski JM, Kundu SD, Eskandari MK. Fifteen-year experience with renal cell carcinoma with associated venous tumor thrombus. Surgery. 2016;160(4):915-23.

8. Agochukwu N, Shuch B. Clinical management of renal cell carcinoma with venous tumor thrombus. World J Urol. 2014;32(3):581-9.

9. Shao P, Li J, Qin C, Lv Q, Ju X, Li P, et al. Laparoscopic Radical Nephrectomy and Inferior Vena Cava Thrombectomy in the Treatment of Renal Cell Carcinoma. Eur Urol. 2015;68(1):115-22. 
10. Miller BS, Doherty GM. Surgical management of adrenocortical tumours. Nat Rev Endocrinol. 2014;10(5):282-92.

11. van Houdt WJ, Zaidi S, Messiou C, Thway K, Strauss DC, Jones RL. Treatment of retroperitoneal sarcoma: current standards and new developments. Curr Opin Oncol. 2017;29(4):260-7.

12. Thalji SZ, Tsai S, Gamblin TC, Clarke C, Christians K, Charlson J, et al. Outcomes of palliative-intent surgery in retroperitoneal sarcoma-Results from the US Sarcoma Collaborative. J Surg Oncol. 2020;121(7):1140-7.

13. Fiore M, Colombo C, Locati P, Berselli M, Radaelli S, Morosi C, et al. Surgical technique, morbidity, and outcome of primary retroperitoneal sarcoma involving inferior vena cava. Ann Surg Oncol. 2012;19(2):511-8.

14. Liu Z, Zhang L, Hong P, Li L, Tang S, Zhao X, et al. The influence of venous tumor thrombus combined with bland thrombus on the surgical treatment and prognosis of renal cell carcinoma patients. Cancer Med. 2020;9(16):5860-8.

15. Blute ML, Leibovich BC, Lohse CM, Cheville JC, Zincke H. The Mayo Clinic experience with surgical management, complications and outcome for patients with renal cell carcinoma and venous tumour thrombus. BJU Int. 2004;94(1):33-41.

16. Pringle JH. V. Notes on the Arrest of Hepatic Hemorrhage Due to Trauma. Ann Surg. 1908;48(4):541-9.

17. Mandal S, Sankhwar SN, Kathpalia R, Singh MK, Kumar M, Goel A, et al. Grading complications after transurethral resection of prostate using modified Clavien classification system and predicting complications using the Charlson comorbidity index. Int Urol Nephrol. 2013;45(2):347-54.

18. Laan DV, Thiels CA, Glasgow A, Wise KB, Thompson GB, Richards ML, et al. Adrenocortical carcinoma with inferior vena cava tumor thrombus. Surgery. 2017;161(1):240-8.

19. Vuong N-S, Ferriere J-M, Michiels C, Calen L, Tesi L, Capon G, et al. Robot-assisted versus open surgery for radical nephrectomy with level 1-2 vena cava tumor thrombectomy: a French monocenter experience (UroCCR study \#73). Minerva Urol Nefrol. 2020.

20. Treiger BF, Humphrey LS, Peterson CV, Oesterling JE, Mostwin JL, Reitz BA, et al. Transesophageal echocardiography in renal cell carcinoma: an accurate diagnostic technique for intracaval neoplastic extension. J Urol. 1991;145(6):1138-40.

\section{Tables}

Table 1 PUTH grading system of adrenal tumor thrombus with vein based on surgical technique

\begin{tabular}{|c|c|c|c|c|}
\hline $\begin{array}{l}\text { Classification } \\
\text { abbreviation }\end{array}$ & $\begin{array}{l}\text { Graded } \\
\text { full name }\end{array}$ & describe & $\begin{array}{l}\text { case } \\
\text { load }\end{array}$ & Description of surgical technique \\
\hline PUTH-1a & $\begin{array}{l}\text { Adrenal } \\
\text { PUTH 1a } \\
\text { grade } \\
\text { tumor } \\
\text { thrombus }\end{array}$ & $\begin{array}{l}\text { Cancer thrombus is } \\
\text { confined to the } \\
\text { central adrenal vein }\end{array}$ & 2 & Hem-o-lok was used to clamp or cut off the central adrenal vein. \\
\hline PUTH-1b & $\begin{array}{l}\text { Adrenal } \\
\text { PUTH } 1 b \\
\text { grade } \\
\text { tumor } \\
\text { thrombus }\end{array}$ & $\begin{array}{l}\text { The tumor thrombus } \\
\text { entered the left renal } \\
\text { vein along the left } \\
\text { central adrenal vein, } \\
\text { but did not enter the } \\
\text { inferior vena cava }\end{array}$ & 2 & $\begin{array}{l}\text { During the operation, the inferior vena cava was partially blocked by side-wall forceps, and } \\
\text { the left renal vein was incised during the operation. After taking out the tumor thrombus, the } \\
\text { left renal vein was sutured. If tumor thrombus invades the wall of left renal vein, Hem-o-lok } \\
\text { clamp or straight-line cutter should be used to cut off the left renal vein. }\end{array}$ \\
\hline PUTH-2 & $\begin{array}{l}\text { Adrenal } \\
\text { puth } \\
\text { grade } 2 \\
\text { tumor } \\
\text { thrombus }\end{array}$ & $\begin{array}{l}\text { The tumor thrombus } \\
\text { invades the inferior } \\
\text { vena cava, and its } \\
\text { proximal end is } \\
\text { located under the } \\
\text { liver }\end{array}$ & 6 & $\begin{array}{l}\text { If the distal end of the tumor thrombus is located above the level of renal vein, the vena } \\
\text { cava of the distal end of the tumor thrombus is blocked by the vascular blocking tape in } \\
\text { turn, and the inferior vena cava is cut after the tumor thrombus is close to the vena cava. If } \\
\text { the distal end of the tumor thrombus is below the level of renal vein, vascular occlusion } \\
\text { needs to block the blood reflux of the healthy renal vein at the same time. }\end{array}$ \\
\hline PUTH-3 & $\begin{array}{l}\text { Adrenal } \\
\text { puth } \\
\text { grade } 3 \\
\text { tumor } \\
\text { thrombus }\end{array}$ & $\begin{array}{l}\text { The tumor thrombus } \\
\text { invades the inferior } \\
\text { vena cava, and its } \\
\text { proximal end is } \\
\text { located behind the } \\
\text { liver }\end{array}$ & 6 & $\begin{array}{l}\text { During the operation, the liver ligament was severed, the inferior vena cava behind the liver } \\
\text { was exposed and dissociated, and the first hepatic portal was dissociated by Pringer } \\
\text { method. The distal vena cava, the first hepatic portal vein, the contralateral renal vein and } \\
\text { the proximal vena cava of the tumor thrombus were blocked in turn by the vascular } \\
\text { blocking band, and then the inferior vena cava was cut to remove the thrombus. }\end{array}$ \\
\hline PUTH-4 & $\begin{array}{l}\text { Adrenal } \\
\text { puth } \\
\text { grade } 4 \\
\text { tumor } \\
\text { thrombus }\end{array}$ & $\begin{array}{l}\text { The tumor thrombus } \\
\text { invaded the inferior } \\
\text { vena cava and } \\
\text { reached above the } \\
\text { diaphragm }\end{array}$ & 3 & $\begin{array}{l}\text { You can cut the diaphragm central tendon around the vena cava or cut the diaphragm } \\
\text { directly, gently push and squeeze the tumor thrombus into the inferior vena cava, so that the } \\
\text { tumor thrombus changes from above the diaphragm to below the diaphragm, and then take } \\
\text { out the tumor thrombus; Conventional methods need to open the chest to establish } \\
\text { cardiopulmonary bypass, and open the right atrium to remove thrombus under the } \\
\text { condition of hypothermic cardiac arrest or non-cardiac arrest. }\end{array}$ \\
\hline
\end{tabular}

Table 2 Baseline characteristics of all 19 patients 


\begin{tabular}{|c|c|}
\hline Characteristics & Result \\
\hline Age (yr), median & $42(16-69)$ \\
\hline Gender, male/female & $7 / 12$ \\
\hline BMI (kg/m2), median & $24.1(18.3-36.2)$ \\
\hline \multicolumn{2}{|l|}{ Affected kidney, n } \\
\hline Left & 6 \\
\hline Right & 13 \\
\hline Tumor size $(\mathrm{cm})$, median & $9.1(2.8-18.3)$ \\
\hline \multicolumn{2}{|l|}{ Clinical $\mathrm{N}$ stage, $\mathrm{n}$} \\
\hline cNO & 13 \\
\hline cN1 & 6 \\
\hline \multicolumn{2}{|l|}{ clinical M stage, $\mathrm{n}$} \\
\hline cMO & 13 \\
\hline cM1 & 6 \\
\hline IVC thrombus length (cm), mean (SD) & $4.0(1.0-12.3)$ \\
\hline \multicolumn{2}{|l|}{ Clinical symptoms, $\mathrm{n}$} \\
\hline No & 8 \\
\hline Local symptoms & 8 \\
\hline Systemic symptoms & 3 \\
\hline SD = standard deviation. & \\
\hline
\end{tabular}




\begin{tabular}{|c|c|c|c|c|c|c|c|c|c|c|c|c|c|c|}
\hline ID & Pathology & $\begin{array}{l}\text { PUTH } \\
\text { Grade }\end{array}$ & Mayo & Gender & Age & $\begin{array}{l}\text { BMI } \\
\left(\mathrm{kg} / \mathrm{m}^{2}\right)\end{array}$ & Symptoms & Side & $\begin{array}{l}\text { Diameter } \\
(\mathrm{cm})\end{array}$ & $\begin{array}{l}\text { ASA } \\
\text { Grade }\end{array}$ & $\begin{array}{l}\mathrm{cN} \\
\text { stage }\end{array}$ & $\begin{array}{l}\mathrm{cM} \\
\text { stage }\end{array}$ & $\begin{array}{l}\text { Combined } \\
\text { thrombi }\end{array}$ & $\begin{array}{l}\text { Thron } \\
\text { Lengt } \\
(\mathrm{cm})\end{array}$ \\
\hline 1 & ccRCC & $\begin{array}{l}\text { PUTH } \\
4\end{array}$ & $\nabla$ & $\mathrm{F}$ & 68 & 23.8 & Systemic & $\mathrm{R}$ & 6.3 & 3 & $\mathrm{cN} 1$ & M1 & $\mathrm{N}$ & 5.5 \\
\hline 2 & Leiomyosarcoma & $\begin{array}{l}\text { PUTH } \\
2\end{array}$ & ? & M & 31 & 20.3 & Local & $\mathrm{R}$ & 9.0 & 2 & cN1 & MO & Y & 4.0 \\
\hline 3 & PHEO & $\begin{array}{l}\text { PUTH } \\
3\end{array}$ & $\nabla$ & M & 44 & 21.0 & Local & $\mathrm{R}$ & 10.0 & 3 & $\mathrm{cNO}$ & MO & Y & 4.7 \\
\hline 4 & ACC & $\begin{array}{l}\text { PUTH } \\
3\end{array}$ & ? & $\mathrm{F}$ & 31 & 30.4 & Local & $\mathrm{R}$ & 15.0 & 2 & $\mathrm{cNO}$ & MO & $\mathrm{N}$ & 5.0 \\
\hline 5 & N.A & $\begin{array}{l}\text { PUTH } \\
2\end{array}$ & ? & $\mathrm{F}$ & 67 & 28.9 & Local & L & 2.8 & 2 & $\mathrm{cN} 1$ & M1 & $\mathrm{N}$ & 5.9 \\
\hline 6 & $\begin{array}{l}\text { Adrenal } \\
\text { adenoma }\end{array}$ & $\begin{array}{l}\text { PUTH } \\
\text { 1a }\end{array}$ & 0 & $\mathrm{~F}$ & 42 & 33.7 & No & L & 7.9 & 2 & $\mathrm{cNO}$ & MO & $\mathrm{N}$ & 1.3 \\
\hline 7 & Ewing Sarcoma & $\begin{array}{l}\text { PUTH } \\
4\end{array}$ & ? & $\mathrm{F}$ & 20 & 18.6 & Local & $\mathrm{R}$ & 18.3 & 4 & $\mathrm{cNO}$ & M1 & $\mathrm{N}$ & 12.3 \\
\hline 8 & ACC & $\begin{array}{l}\text { PUTH } \\
1 \mathrm{a}\end{array}$ & 0 & M & 58 & 24.1 & No & $\mathrm{R}$ & 9.4 & 2 & $\mathrm{cNO}$ & MO & $\mathrm{N}$ & 1.5 \\
\hline 9 & Leiomyosarcoma & $\begin{array}{l}\text { PUTH } \\
3\end{array}$ & ? & M & 55 & 18.3 & No & $\mathrm{R}$ & 10.7 & 2 & $\mathrm{cNO}$ & Mo & $\mathrm{N}$ & 7.5 \\
\hline 10 & Paraganglioma & $\begin{array}{l}\text { PUTH } \\
2\end{array}$ & 1 & M & 16 & 21.0 & Systemic & $\mathrm{R}$ & 9.1 & 1 & $\mathrm{cNO}$ & MO & $\mathrm{N}$ & 1.0 \\
\hline 11 & Leiomyosarcoma & $\begin{array}{l}\text { PUTH } \\
4\end{array}$ & $\nabla$ & $\mathrm{F}$ & 57 & 24.7 & Local & $\mathrm{R}$ & 7.1 & 3 & $\mathrm{cN} 1$ & M1 & $\mathrm{N}$ & 12.0 \\
\hline 12 & Leiomyosarcoma & $\begin{array}{l}\text { PUTH } \\
3\end{array}$ & प & $\mathrm{F}$ & 56 & 28.7 & No & $\mathrm{R}$ & 5.8 & 2 & $\mathrm{cNO}$ & M1 & $\mathrm{N}$ & 2.8 \\
\hline 13 & ACC & $\begin{array}{l}\text { PUTH } \\
2\end{array}$ & $\nabla$ & $\mathrm{F}$ & 56 & 36.2 & No & $\mathrm{R}$ & 6.5 & 3 & $\mathrm{cNO}$ & MO & $\mathrm{N}$ & 4.0 \\
\hline 14 & PHEO & $\begin{array}{l}\text { PUTH } \\
1 \mathrm{~b}\end{array}$ & 0 & $\mathrm{~F}$ & 35 & 21.5 & No & L & 7.4 & 2 & $\mathrm{cNO}$ & MO & $\mathrm{N}$ & 2.3 \\
\hline 15 & ACC & $\begin{array}{l}\text { PUTH } \\
2\end{array}$ & ] & $F$ & 49 & 21.5 & Local & L & 12.2 & 2 & $\mathrm{cNO}$ & MO & $\mathrm{N}$ & 4.0 \\
\hline 16 & ACC & $\begin{array}{l}\text { PUTH } \\
3\end{array}$ & ( & $\mathrm{F}$ & 69 & 23.1 & Systemic & $\mathrm{R}$ & 12.5 & 2 & $\mathrm{cN} 1$ & M1 & $\mathrm{N}$ & 3.0 \\
\hline 17 & ACC & $\begin{array}{l}\text { PUTH } \\
2\end{array}$ & [ & $\mathrm{F}$ & 54 & 26.0 & No & $\mathrm{R}$ & 7.1 & 2 & $\mathrm{cNO}$ & MO & $\mathrm{N}$ & 3.3 \\
\hline 18 & $\begin{array}{l}\text { Adrenal } \\
\text { neuroblastoma }\end{array}$ & $\begin{array}{l}\text { PUTH } \\
3\end{array}$ & ( & M & 38 & 25.1 & Local & L & 10.3 & 2 & $\mathrm{cN} 1$ & MO & $\mathrm{N}$ & 7.0 \\
\hline 19 & PHEO & $\begin{array}{l}\text { PUTH } \\
1 \mathrm{~b}\end{array}$ & 0 & M & 53 & 24.2 & No & L & 8.8 & 2 & $\mathrm{cNO}$ & MO & $\mathrm{N}$ & 2.5 \\
\hline
\end{tabular}

ccRCC=clear cell renal cell carcinoma; $\mathrm{PHEO}=$ pheochromocytoma; $\mathrm{ACC}=$ adrenal cortical carcinoma; $\mathrm{N}$.A=Pathological type was unclear

Table 4 - Perioperative data and pathologic result of 19 patients 


\begin{tabular}{|c|c|}
\hline Characteristics & Result \\
\hline Operative time (min), median (IQR) & $342(153-575)$ \\
\hline Estimated blood loss (ml), median (IQR) & $1300(200-4500)$ \\
\hline Patients receiving transfusion, $\mathrm{n}(\%)$ & 14(73.7) \\
\hline Postoperative hospital stay (d), mean (SD) & $8(4-44)$ \\
\hline \multicolumn{2}{|l|}{ ASA grade, $n(\%)$} \\
\hline Grade $\triangle$ & $1(5.3)$ \\
\hline Grade $\triangle$ & 13(68.4) \\
\hline Grade $\square$ & $4(21.1)$ \\
\hline Grade $\triangle$ & $1(5.3)$ \\
\hline Postoperative complication, n (\%) & $5(26.3)$ \\
\hline Preoperative serum $\mathrm{Cr}(\mu \mathrm{mol} / \mathrm{I})$, median (IQR) & $68(48-90)$ \\
\hline Postoperative (1 wk) serum $\mathrm{Cr}(\mu \mathrm{mol} / \mathrm{l})$, median (IQR) & $66(41-129)$ \\
\hline IVC wall invasion, n (\%) & $6(31.6)$ \\
\hline Presence of bland thrombus, $\mathrm{n}(\%)$ & $2(10.5)$ \\
\hline Lymph node metastasis, $\mathrm{n}(\%)$ & $3(15.8)$ \\
\hline
\end{tabular}

$\mathrm{IQR}=$ interquartile range; $\mathrm{SD}$ = standard deviation; $\mathrm{ASA}=$ American Society of Anesthesiologists;

$\mathrm{Hb}=$ hemoglobin; $\mathrm{Cr}=$ creatinine; $\mathrm{BUN}=$ blood urea nitrogen; $\mathrm{ccRCC}$ = clear cell renal cell carcinoma; IVC = inferior vena cava .

Data presented as mean (SD) or median (IQR), unless otherwise noted

Table 5 Operation Data of patients in our cohort $₫ n=19 \bigotimes$

\begin{tabular}{|c|c|c|c|c|c|c|c|c|}
\hline ID & Approach & Ipsilateral nephrectomy & Time & $\begin{array}{l}\text { Blood } \\
\text { loss }\end{array}$ & $\begin{array}{l}\text { RCS } \\
\text { transfusion }\end{array}$ & $\begin{array}{l}\text { Plasma } \\
\text { transfusion }\end{array}$ & $\begin{array}{l}\mathrm{LN} \\
\text { resection }\end{array}$ & $\begin{array}{l}\text { Segmental } \\
\text { IVC resection }\end{array}$ \\
\hline 1 & Lap to 0 & Y & 526 & 2000 & 800 & 0 & Y & $\mathrm{N}$ \\
\hline 2 & 0 & Y & 288 & 400 & 0 & 0 & $\mathrm{~N}$ & $\mathrm{~N}$ \\
\hline 3 & 0 & $\mathrm{~N}$ & 486 & 2700 & 1600 & 800 & $\mathrm{~N}$ & $\mathrm{~N}$ \\
\hline 4 & 0 & $\mathrm{~N}$ & 504 & 3500 & 3200 & 1400 & $\mathrm{~N}$ & $\mathrm{~N}$ \\
\hline 5 & 0 & $\mathrm{~N}$ & 216 & 1500 & 1200 & 0 & $\mathrm{~N}$ & $\mathrm{~N}$ \\
\hline 6 & Lap & $\mathrm{N}$ & 153 & 200 & 0 & 0 & $\mathrm{~N}$ & $\mathrm{~N}$ \\
\hline 7 & 0 & $\mathrm{~N}$ & 587 & 4500 & 2800 & 2200 & $\mathrm{~N}$ & $\mathrm{~N}$ \\
\hline 8 & Lap & $\mathrm{N}$ & 193 & 200 & 0 & 0 & $\mathrm{~N}$ & $\mathrm{~N}$ \\
\hline 9 & 0 & Y & 256 & 800 & 800 & 0 & $\mathrm{~N}$ & $\mathrm{~N}$ \\
\hline 10 & 0 & $Y$ & 329 & 1000 & 1200 & 400 & $\mathrm{~N}$ & $\mathrm{~N}$ \\
\hline 11 & 0 & $\mathrm{~N}$ & 297 & 2000 & 2800 & 800 & $\mathrm{~N}$ & $Y$ \\
\hline 12 & 0 & $\mathrm{~N}$ & 377 & 900 & 600 & 0 & $\mathrm{~N}$ & $\mathrm{~N}$ \\
\hline 13 & Lap & $\mathrm{N}$ & 335 & 800 & 400 & 0 & $\mathrm{~N}$ & $\mathrm{~N}$ \\
\hline 14 & Lap & $\mathrm{N}$ & 217 & 100 & 0 & 0 & $Y$ & $\mathrm{~N}$ \\
\hline 15 & 0 & $Y$ & 440 & 2000 & 1600 & 400 & $Y$ & $\mathrm{~N}$ \\
\hline 16 & 0 & $\mathrm{~N}$ & 355 & 3500 & 2800 & 1400 & Y & $\mathrm{N}$ \\
\hline 17 & 0 & $\mathrm{~N}$ & 261 & 900 & 0 & 0 & $\mathrm{~N}$ & $\mathrm{~N}$ \\
\hline 18 & 0 & $Y$ & 575 & 3300 & 2800 & 1600 & Y & $\mathrm{N}$ \\
\hline 19 & Lap & $\mathrm{N}$ & 429 & 1600 & 800 & 400 & $\mathrm{~N}$ & $\mathrm{~N}$ \\
\hline
\end{tabular}

Lap to $\mathrm{O}=$ laparoscopic approach to open approach; $\mathrm{O}=$ open approach; $\mathrm{Lap}=$ laparoscopic approach 
Table 6 Postoperative Data of patients in our cohort $₫ n=19 \rrbracket$

\begin{tabular}{|c|c|c|c|c|c|c|c|c|c|c|}
\hline ID & $\begin{array}{l}\text { Postoperative } \\
\text { stay }\end{array}$ & $\begin{array}{l}\text { Pre-Cr } \\
(\mu \mathrm{mol} / \mathrm{L})\end{array}$ & $\begin{array}{l}\text { Post-Cr } \\
(\mu \mathrm{mol} / \mathrm{L})\end{array}$ & $\begin{array}{l}\mathrm{pN} \\
\text { stage }\end{array}$ & $\begin{array}{l}\text { IVC } \\
\text { invasion }\end{array}$ & Complications & $\begin{array}{l}\text { Follow- } \\
\text { up }\end{array}$ & Status & Recurrence & $\begin{array}{l}\text { Postoperative } \\
\text { treatment }\end{array}$ \\
\hline 1 & 8 & 54 & 53 & $\mathrm{pN} 1$ & $\mathrm{~N}$ & Infection & 69.0 & Alive & Lung & Sunitinib \\
\hline 2 & 8 & 88 & 129 & pNO & $Y$ & - & 49.0 & Alive & No & - \\
\hline 3 & 10 & 81 & 66 & pNO & $Y$ & Anemia & 41.0 & Alive & No & - \\
\hline 4 & 9 & 63 & 66 & pNO & $\mathrm{N}$ & Anemia & 10.0 & Alive & $\begin{array}{l}\text { Liver } \\
\text { metastasis }\end{array}$ & Radiotherapy \\
\hline 5 & 8 & 67 & 87 & pNO & N.A & - & 7.0 & Alive & No & - \\
\hline 6 & 4 & 48 & 54 & pNO & $\mathrm{N}$ & - & 3.0 & Alive & Lymph node & Chemotherapy \\
\hline 7 & 44 & 67 & 118 & pNO & $\mathrm{N}$ & Anemia & 21.0 & Alive & No & - \\
\hline 8 & 5 & 65 & 57 & pNO & $\mathrm{N}$ & - & 5.0 & Alive & No & - \\
\hline 9 & 6 & 74 & 93 & pNO & $\mathrm{N}$ & - & 27.0 & Alive & No & - \\
\hline 10 & 8 & 90 & 81 & $\mathrm{pNO}$ & $Y$ & - & 26.0 & Alive & No & - \\
\hline 11 & 16 & 78 & 64 & pNO & $Y$ & - & 7.0 & Dead & No & - \\
\hline 12 & 13 & 68 & 41 & pNO & $\mathrm{N}$ & $\begin{array}{l}\text { Pulmonary } \\
\text { embolism }\end{array}$ & 24.0 & Alive & No & - \\
\hline 13 & 8 & 54 & 58 & pNO & $\mathrm{N}$ & - & 7.0 & Alive & Multiple organ & - \\
\hline 14 & 5 & 60 & 87 & pNO & $\mathrm{N}$ & - & 22.0 & Alive & No & - \\
\hline 15 & 9 & 56 & 45 & pNO & $\mathrm{Y}$ & - & 16.0 & Alive & - & - \\
\hline 16 & 10 & 71 & 50 & $\mathrm{pN} 1$ & $\mathrm{~N}$ & - & 11.0 & Dead & Liver & - \\
\hline 17 & 5 & 75 & 88 & pNO & $\mathrm{N}$ & - & 14.0 & Dead & Retroperitoneal & Immnotherapy \\
\hline 18 & 12 & 90 & 103 & $\mathrm{pN} 1$ & $\mathrm{Y}$ & - & 9.0 & Alive & Diaphragmatic & Erlotinib \\
\hline 19 & 4 & 71 & 93 & pNO & $\mathrm{N}$ & - & 3.0 & Alive & No & - \\
\hline
\end{tabular}

\section{Figures}




\begin{tabular}{|l|l|l|}
\hline $\begin{array}{l}\text { Classification } \\
\text { abbreviation }\end{array}$ & $\begin{array}{l}\text { Typical enhanced CT } \\
\text { findings }\end{array}$ & $\begin{array}{l}\text { Schematic diagram of venous } \\
\text { thrombosis and surgical procedures }\end{array}$ \\
\hline PUTH-1a & & \\
\hline PUTH-1b & & \\
\hline PUTH-2 & \\
\hline PUTH-4
\end{tabular}

\section{Figure 1}

Typical imaging manifestations and schematic diagram of PUTH grading system for adrenal gland with venous thrombosis 